Issue no. 26/2018

\title{
CHANGES IN THE EUROPEAN DEVELOPMENT POLICY AFTER 2020. CONCLUSIONS FOR THE VISEGRÁD GROUP
}

\author{
Dr. Bartosz Jankowski \\ Institute of Political Science \\ Cardinal Stefan Wyszyński University in Warsaw \\ b.jankowski@gmail.com
}

DOI:10.24193/OJMNE.2018.26.05

\begin{abstract}
The purpose of this paper is to analyze the changes that will take place in the development policy of the European Union after 2020 from the perspective of the Visegrád Group states. The article begins from a short description of the systems of development cooperation among the four states of the Visegrád Group. The analysed elements are i.a.: evolution of engagement of V4 states in development cooperation and assumptions of their assistance programmes, particularly the assisted sectors and countries. Through the above, the author indicates that the V4 states have a similar historical experience of their cooperation with developing countries and their development programmes have similar characteristics (for example, the assistance level, supported sectors and countries) and problems, i.a. in execution of their international obligations. As a result, the V4 states are not in the centre of the debate on development assistance. The next part of the article analyses the conditions of development policies, indicating both changes in the international environment of the European Union, such as the increasing differentiation among the developing countries, growth of the position of BRIC countries or adoption of the new development agenda, and also the changes that have occurred within the European Union itself, including i.a.: institutional changes and Brexit. The above constitutes the basis for the analysis of potential changes in the development policy of the European Union after 2020. The paper ends with an analysis of the challenges faced by the V4 states on their way to effective participation in international development cooperation.
\end{abstract}

Keywords: development assistance, Visegrád Group, V4, European Union, sustainable development goals

\section{Introduction}

Development policy is one of the key areas of foreign relations of the European Union. Due to the significant funds dedicated to it, the European Commission and the 
member states are jointly the most important entities creating international development cooperation as they constitute more than a half of the official world development assistance.

The purpose of this paper is to analyse the future changes in the development policy of the European Union after 2020 from the perspective of the Visegrád Group states (V4). The adoption of new perennial frames of financing and new assumptions of cooperation with countries of Africa, the Pacific and the Caribbean gives an opportunity to modify the development policy in a way that it reflects the conditions and interests of the European Union in the forthcoming years in a better way. It will not happen without influencing policies of individual member states.

The V4 states seem to be an interesting case due to a number of reasons. In spite of some experience dating back to the times of the Cold War, the states are still called “emerging donors". In the 1990s, the V4 countries had to build their capacity of development cooperation from almost nothing. As a result of many weaknesses, their policies are often different from international practices. A substantial part of their development assistance is distributed through the European Union and due to that they might be significantly affected by the mentioned changes. Ignoring their importance might result in V4 continuing to distance itself from accepted international practices, which would in turn deteriorate their position in the European Union. At the same time, analysing the V4 case allows drawing broader conclusions relating to challenges faced by all South-East European member states of the EU.

To do that, it is necessary to answer the following questions: What are the assumptions of the development policy of the V4 countries, particularly what are their goals and directions of action? What factors will condition development cooperation in the forthcoming years? What will be their influence on the development policy of the European Union? What could be another, better form of assistance programmes of the V4? What particular changes should the V4 countries introduce to adjust their policies to changes in international, particularly the Union's, development policy? What are the biggest challenges faced within this area?

This article has the following structure: the first part begins with a short description of systems of development cooperation of the four countries of the Visegrád Group. The author proves that the V4 countries have similar historical experience of cooperation with 
developing countries and their assistance programmes have similar characteristics (for example, the level of assistance, supported sectors and states) and face similar problems. The V4 countries are out of the main debate on development cooperation and struggle with the execution of many obligations in this area. The second part is dedicated to analysing the factors conditioning development policies. The author indicates changes in the international environment of the European Union, such as the growing diversity of the developing countries or the adoption of the new development agenda and the changes that have occurred within the European Union itself. Among them the author analyses institutional changes and Brexit. That constitutes the basis of the third part, describing potential changes in the development policy of the European Union after 2020. The fourth part of the article is dedicated to challenges that the V4 countries must face to effectively participate in international development cooperation.

\section{Development cooperation of the countries of the Visegrád Group}

In spite of the fact that the V4 countries are often called "emerging donors", they have provided international assistance for quite a long time since the 1950s. Their programmes work in a similar historical context. Before transition, the V4 states did not pursue a fully independent foreign policy and their actions used to be in accordance with the ideological and political interests of the Soviet Union. Their policies were coordinated by the Council for Mutual Economic Assistance. Within its scope, the main effort was directed towards other socialist states or allied authoritarian regimes, including receivers like Cuba, Vietnam, North Korea, Mongolia and Angola. Its basis was constituted by technical and scientific cooperation covering the supply of equipment, experts, trainings, scholarships and subsidized loans. The above-mentioned actions had little to do with actual assistance in economic development as their beneficiaries were selected through political decisions. Those states were important from the perspective of the geopolitical interests of the USSR and the transferred aid was mainly used to support communist regimes (Szent-Iványi and Tétényi, 2013: 820-821). At its peak, in the 1970s, the assistance provided by Central and Eastern European states may have had the total value of around 300 million USD, but due to combining development assistance with economic and military cooperation, it is difficult to assess it in a precise manner (Lancaster, 2007: 31; Pavlik, 2016: 38). 
In the 1980s, as a result of growing economic problems, the assistance programmes of V4 were significantly reduced and finally put on hold nearly a decade later. The main focus of the V4 policy was moved to political and economic transformation, and integration with Western structures, as a result of which the remaining aspects of foreign policy, including relations with developing countries, were marginalized (Carbone, 2007: 47).

The transformation caused a major need for financial and technical assistance, which resulted in V4 countries becoming donees rather than donors at the beginning of the 1990s, with the World Bank, IMF, OECD and the European Union among the donors. The main instrument for the distribution of the aid was PHARE (Poland and Hungary: Assistance for Restructuring their Economies) programme. In the first years, its purpose was to transfer nonreturnable aid for the purpose of supporting the processes of economic transformation. Ultimately, the assistance measures were gradually concentrated on long-term economic development goals. In the following years, the programme was supplemented with two others: ISPA and SAPARD. The ISPA programme was launched to support investment projects within the scope of transport infrastructure and environmental protection, and the SAPARD project aimed to cover structural reforms in agriculture (Pavlik, 2016: 36-37). The V4 countries also received support in building their assistance capability from the Canadian “ODA in Central Europe” programme and the "Emerging Donors Initiative” led by UNPD (Szent-Iványi and Tétényi, 2013: 822).

At the end of the 1990s, the V4 countries joined OECD and finished their accession talks with the European Union. By joining those organizations, they undertook to fulfil a number of obligations regarding assistance for developing countries, which resulted in their re-engagement as participants in development cooperation. One of them was the declaration aiming to increase the assistance to the level of 0.33\% of GNI (Horký and Lightfoot, 2012: 34).

The V4 were then recorded in international statistics as donors of small amounts for the execution of humanitarian aid, minor development projects and voluntary contributions for international organizations. It is worth underlining that in spite of their minor character, those were constant actions fulfilling the criteria of Official Development Assistance and they made it possible to gather necessary experience in that area. At that time, the first strategic documents were also developed and works began on regulations at the level of statutory acts 
(Jankowski, 2015: 138-139). NGOs started to be active participants in development assistance. Many of them working in the area of humanitarian aid appeared to answer the needs caused by the civil war in Yugoslavia and the conflicts in the former Soviet Union. The most important to be mentioned are Polish Humanitarian Action and Czech People in Need (Grimm and Harmer, 2005: 8-9).

Chart 1. The Official Development Assistance provided by the states of the Visegrád Group (in millions of USD in relation to current prices)

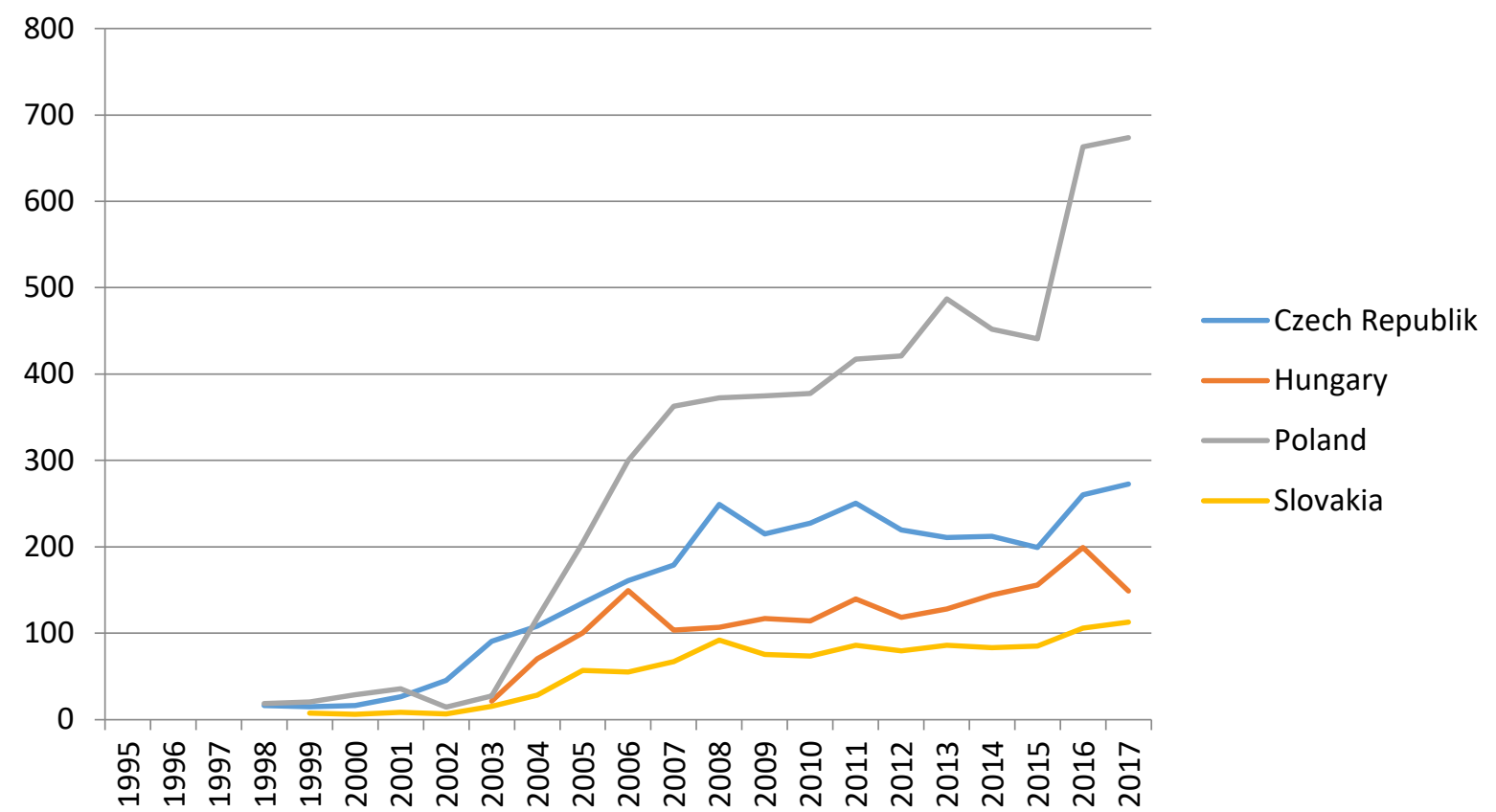

Source: OECD, Total flows by donor. OECD http://stats.oecd.org/viewhtml.aspx?datasetcode=TABLE1\&lang=en\# [Accessed 15/04/18].

Chart 1 indicates the level of Official Development Assistance provided by the V4 states. Their expenditure dedicated to development assistance is one of the lowest among the members of OECD and the European Union. A clear growth of the volume came no sooner than in 2004. When joining the European Union, the V4 countries paid their member contribution, part of which was dedicated to cooperation for development. That situation meant a growth of the amount of provided assistance to the level of several hundred million dollars. Before that, the assistance expenditure had not been higher than a dozen or so million dollars and the average value of aid donated until 2003 had only been 22.4 million dollars. This growth seems to be more a result of unwanted obligations resulting from the 
Issue no. $26 / 2018$

membership of the European Union than a conscious political decision. The rapid increase in expenditure for ODA was continued until 2008. After that year, the V4 countries decreased their assistance due to the economic crisis. In spite of the relatively high dynamic of the nominal growth, the relation of ODA to DNB is still small, amounting to between $0.11 \%$ and $0.13 \%$ (the average for DAC OECD countries is $0.31 \%$ ). It is worth mentioning that over $70 \%$ of the development aid of V4 is transferred via international organizations, mainly the European Union.

Table 1. The Official Development Assistance of the Visegrád Group states in 2016

\begin{tabular}{|c|c|c|c|c|}
\hline & Poland & Hungary & Slovakia & Czech Republic \\
\hline ODA \%GNI & $0,13 \%$ & $0,11 \%$ & $0,12 \%$ & $0,13 \%$ \\
\hline $\begin{array}{l}\text { ODA in millions of } \\
\text { USD }\end{array}$ & 662,9 & 199,1 & 106,0 & 260,2 \\
\hline ODA bilateral & 207,0 & 59,7 & 27,5 & 72,4 \\
\hline ODA multilateral & 455,9 & 139,4 & 78,5 & 187,8 \\
\hline Priority countries & $\begin{array}{l}\text { Belarus, Georgia, } \\
\text { Moldova, Ukraine, } \\
\text { Ethiopia, Kenya, } \\
\text { Myanmar, Palestine, } \\
\text { Senegal, Tanzania }\end{array}$ & $\begin{array}{l}\text { West Balkans, Eastern } \\
\text { Europe }\end{array}$ & $\begin{array}{l}\text { Programme countries: } \\
\text { Afghanistan, Kenya, } \\
\text { Moldova } \\
\text { Project countries: } \\
\text { Albania, Belarus, } \\
\text { Bosnia and } \\
\text { Herzegovina, } \\
\text { Georgia, Kosovo, } \\
\text { Ukraine }\end{array}$ & $\begin{array}{l}\text { Bosnia and } \\
\text { Herzegovina, } \\
\text { Cambodia, Ethiopia, } \\
\text { Georgia, Moldova, } \\
\text { Zambia. }\end{array}$ \\
\hline Subject priorities & $\begin{array}{l}\text { Good governance, } \\
\text { democracy and } \\
\text { human rights, human } \\
\text { capital, } \\
\text { entrepreneurship and } \\
\text { private sector, } \\
\text { sustainable agriculture } \\
\text { and development of } \\
\text { rural areas, } \\
\text { environmental } \\
\text { protection }\end{array}$ & $\begin{array}{l}\text { Institutional } \\
\text { development, green } \\
\text { growth, } \\
\text { environmental and } \\
\text { climate protection, } \\
\text { human development }\end{array}$ & $\begin{array}{l}\text { Education, health, } \\
\text { good governance, } \\
\text { development of civic } \\
\text { society, water and } \\
\text { sanitary facilities, } \\
\text { energy, support for } \\
\text { development of } \\
\text { market environment }\end{array}$ & $\begin{array}{l}\text { Good governance, } \\
\text { sustainable } \\
\text { management of natural } \\
\text { resources, economic } \\
\text { transformation and } \\
\text { growth, agriculture and } \\
\text { development of rural } \\
\text { areas, inclusive social } \\
\text { development }\end{array}$ \\
\hline Main donees & $\begin{array}{l}\text { Ethiopia 42,3 M } \\
\text { Ukraine 24,1 M } \\
\text { Tanzania 22,9 M } \\
\text { Belarus 19,2 M } \\
\text { Turkey 18,1 M }\end{array}$ & $\begin{array}{l}\text { Turkey 11,8 M } \\
\text { Laos 3,1 M } \\
\text { China 2,4 M } \\
\text { Sri Lanka 2,1 M } \\
\text { Serbia 2,1 M }\end{array}$ & $\begin{array}{l}\text { Serbia (1,1 M USD) } \\
\text { Ukraine }(1,6 \mathrm{M}) \\
\text { Kenya }(2,11 \mathrm{M}) \\
\text { Montenegro }(0,58 \mathrm{M}) \\
\text { Moldova }(0,46 \mathrm{M})\end{array}$ & $\begin{array}{l}\text { Mongolia 4,1 M } \\
\text { Jordan 3,4 M } \\
\text { Ethiopia 3,2 M } \\
\text { B\&H 3 M } \\
\text { Georgia 2,8 M } \\
\end{array}$ \\
\hline Assistance per region & $\begin{array}{l}\text { Europe 59,3 M } \\
\text { Africa 80,2 M } \\
\text { America 0,31 M } \\
\text { Asia } 0 \mathrm{M} \\
\text { Unspecified 9,3 M }\end{array}$ & $\begin{array}{l}\text { Europe 16,9 M } \\
\text { Africa 6,3 M } \\
\text { America 0,9 M } \\
\text { Asia 19,5 M } \\
\text { Unspecified 11,2 M }\end{array}$ & $\begin{array}{l}\text { Europe } 5,7 \mathrm{M} \\
\text { Africa } 2,4 \mathrm{M} \\
\text { America } 0,5 \mathrm{M} \\
\text { Asia } 1,8 \mathrm{M} \\
\text { Unspecified } 15,2 \mathrm{M}\end{array}$ & $\begin{array}{l}\text { Europe } 19,0 \mathrm{M} \\
\text { Africa } 6,3 \mathrm{M} \\
\text { America 0,8 M } \\
\text { Asia 22,8 M } \\
\text { Unspecified } \\
\text { 22,5 mln }\end{array}$ \\
\hline
\end{tabular}

Source: Ministry of Foreign Affairs of the Czech Republic (2017) Development Cooperation Strategy of the Czech Republic 2018-2030. Prague; Ministry of Foreign Affairs and Trade of Hungary (2014) International Development Cooperation Strategy and Strategic Concept for International Humanitarian Aid of Hungary. Budapest; Ministry of Foreign and European Affairs of the Slovak Republic (2013) The Medium - Term Strategy for Development Cooperation of the Slovak Republic for 2014-2018. Bratislava; Ministry of Foreign Affairs Republic of Poland (2015) Multiannual Development 
Cooperation Programme 2016-2020. Warsaw; OECD, Aid (ODA) disbursements to countries and regions. OECD statistics, http://stats.oecd.org/Index.aspx?DataSetCode=TABLE2A\# [Accessed 15/04/18].

The V4 countries have similar geographical and subject priorities. Three basic directions can be indicated while analysing the evolution of the list of priority countries. They are all effects of historical relations and economic and political reasons. The first, most important group of countries being donees of development aid are the neighbouring countries of Eastern Europe (Eastern Partnership initiative), or the Balkans. The second group includes Iraq and Afghanistan, where V4 was or is engaged in stabilizing missions with development cooperation as one of their elements. The last group of priority countries is constituted by selected underdeveloped countries, for example the Palestine National Authority and Ethiopia. This group also includes many countries with which V4 had cooperated before 1989 within the frames of Comecon (Jankowski, 2015: 131-132; Szent-Iványi: 4).

In accordance with recommendations of the UN and OECD, development aid should get to the poorest developing countries, especially African ones. The Sub-Saharan region is the main receiver of the means donated by the European Union. On the other hand, the V4 countries concentrate their actions mainly on the Eastern Partnership and Balkan states. Africa has never played a significant role in the V4 foreign policy and therefore it is usually excluded from assistance programmes. In spite of many promises and declarations, aid for Africa has never gone beyond rhetoric. This situation is a result of a lack of political, historical and economic ties with that region (Kopiński, 2011: 8-10; Lightfoot, 2008: 135). However, some improvement within that scope should be noted, as for example in recent years the assistance provided by Poland to Africa has increased from USD 2.6 M in 2010 to USD $80.3 \mathrm{M}$ in 2016.

There is a rather distant relation between the list of priority countries and those which receive most of the bilateral aid. The majority of the assistance is provided to states which fail to comply with democratic standards and which have an average level of development due to political and economic reasons. The assistance provided by the V4 countries is fragmented, less effective and visible due to the fact that the support is granted to dozens of countries each year. Consequently, many states receive aid of barely several thousands of dollars. It is mainly a result of the lack of cohesion among the targets of economic diplomacy promoted by the ministries of economy and the targets of foreign policy specified by the 
ministries of foreign affairs (Jankowski, 2015: 132-134). Development assistance is considered to be a means of foreign policy for the creation of a positive image of donors, introducing stability and regional security, supporting democratization in the region, gaining favour of local elites and stimulating economic contacts (Olsen, 2005: 594; Szent-Iványi: 5).

The V4 countries also have a similar sector strategy. In spite of the relatively many declared subject priorities, the development cooperation programmes of V4 reserve a special role for the areas of democratization, human rights and system transformation. The abovementioned areas are especially visible in supporting the partners in Eastern Europe and the Balkans. Choosing them derives from the confidence of having a unique experience of political and economic transformation initiated after 1989 and therefore having an advantage over other donors. This confidence was enhanced after the Arab Spring, when the V4 countries offered their assistance to the states of Northern Africa. For example, Poland claimed Libya and Tunisia to be priority countries (Kugiel, 2012: 106-109).

The above-mentioned confidence is strengthened by the international community, which was expressed i.a. in the European Consensus on Development, stating that: "The EU will capitalize on new Member States’ experience (such as transition management) and help strengthen the role of these countries as new donors” (O.J. EU 2006/C 46/01, 24 February 2006: point 33). In 2010, the European Commission published the European Transition Compendium. OECD shares the European Union's opinion. In the special review of Polish development assistance, DAC stated that: "Polish development assistance focuses on enhancement and promotion of democracy and good governance, human rights, sustainable development and civil society, particularly among its neighbours in Eastern Europe. Poland's own recent experience of transformation gives it a clear comparative advantage in its neighbourhood in these sectors” (OECD, 2010: 13).

\section{The changing context of development cooperation of the European Union}

While making assumptions for its development policy, the European Union must take into account numerous changes that have appeared in its environment, especially in the world economy, international relations, global problems and within itself. Those factors indicate the conditions for the functioning of development assistance of the European Union, especially the challenges it will face. 
The changes in economic and political balance of power, especially the growth of importance of emerging economies pursuing a greater role in global management cause the fact that the European Union is neither the only nor the most important partner of many developing countries. The role of the USA and Europe is decreasing, which leads us to a multipolar world. Within recent years, this process has considerably gained speed with BRIS states (Brasil, Russia, India and China), expected to constitute a third part of the world economy. The dynamic of cooperation among developing countries is governed by different rules and, therefore, the European Union loses its possibility to shape the internal situation of the countries of the South, which are presented with a different vision of economic development and political order, leading it to being perceived as alternative to the European Union. They offer significant financial assistance without interfering with the internal matters of each country. Especially China is more and more engaged in relations with developing countries, offering trade cooperation and political and economic support. Many developing countries are interested in the Chinese economic model due to the fact that on one hand it offers significant commercial effects, but on the other it does not interfere with their internal affairs and therefore poses no threat to authoritarian regimes (Mah, 2014: 9; Odén and Wohlgemuth, 2015:1; Pape, 2013: 729; Vaes and Huyse, 2016: 17).

Developing countries have undergone substantial changes becoming more diversified regarding the level of income and economic results. The economies of many of them have significantly grown in recent years, increasing their income to the intermediate level. NonOECD countries are expected to constitute $60 \%$ of the world GDP in twenty years (Lundsgaarde, 2012: 706). In 2030, the states of the South will represent $70 \%$ of the world consumption and $80 \%$ of its middleclass. As a result of that, the development assistance plays a less and less important role in stimulating their economies, as its amount is smaller than other flows of capital, such as foreign direct investments and money sent by migrants (Odén and Wohlgemuth, 2015: 2-3). It is becoming necessary to adjust the means of cooperation and their diversity to new needs of developing countries, taking into consideration their social and economic conditions. Due to that, the discussion on the future of development cooperation concentrates on measures beyond the traditional development assistance, for example the stimulation of investments, trade etc. (Janus, Klingebiel and Paulo, 2014: 1). 
On the other hand, many developing countries struggle against ferocious internal conflicts, political and economic instability. Poverty is one of the sources of threat to international security as it stimulates the radicalization of societies, generates terrorism, internal conflicts and migration. Consequently, the European Union must take into consideration the decrease in the security level, especially in its vicinity, in North Africa and the Middle East. Development assistance may be a precious measure for solving those problems. Development and security are strictly related to each other. It is claimed that security is a necessary condition of economic development (Bossuyt and Sherriff, 2017: 1). That statement was clearly underlined in the new Global Strategy on Foreign and Security Policy of the European Union. The document sets strategic assessments of the external actions of the European Union. The strategy underlines the direct relation between European security and the economic stability and welfare of the surrounding regions. The aims of sustainable development are to broadly specify the direction of all actions for the execution of the global strategy of the EU (High Representative of the Union for Foreign Affairs and Security Policy, 2016). However, there are doubts concerning the excessive integration of the targets of the development policy with security policy and migration control, which can impose limits on the means and their use for purposes other than social and economic development. Many measures combining development and security have been created in the last decade. It is estimated that between 2001 and 2010 the means combining those targets amounted to EUR 7.7 billion, which constitutes about 10\% of all assistance means governed by the European Commission (CONCORD, 2017: 3; Merket, 2013: 90-91).

The next factor which should be taken into consideration is the changing context of cooperation for development. In 2015, the UN passed Agenda for Sustainable Development 2030 resolution, setting Sustainable Development Goals (A/RES/70/1), which substituted Millenium Development Goals. The new agenda includes 17 targets and 169 obligations. It is also wider and more ambitious than the previous ones, as it covers areas beyond fighting poverty, combining it with social development and environment protection. The new goals comprehensively cover many challenges of the contemporary world, from fighting poverty and hunger, through good quality of education, clean and accessible electrical energy, sustainable cities, equality of genders, limiting inequality, environment protection, climate change, to peace, justice and international partnership. By that, the Agenda covers matters so 
far not directly included in development cooperation. At the same time, it is much more universal as it concerns all countries, independently of their level of development. The assistance donors and donees have the same rights and obligations within the scope of reaching those goals, which undermines the traditional division between givers and receivers. Finally, the agenda establishes a bigger role of the private sector, especially businesses and civic society (Venturi and Magro, 2016: 3-5).

The decisions made at the 2015 United Nations Climate Change Conference held in Paris (COP21) will be of major importance for the talks on the future form of the development cooperation of the European Union. The purpose of the conference was to conclude a common agreement among all countries of the world concerning climate change. It was the first time a global compromise on limiting climate change had been reached. The main arrangements of the agreement are the limitation of global warming and zero emission of greenhouse gases. It is especially important for developing countries as they are particularly vulnerable to the results of climate change such as drought, flood and other natural disasters. Non-sustainable and unjust use of natural resources also deepens inequality among countries.

Furthermore, the decisions made at the Third International Conference on Financing for Development in Addis Ababa in 2015 should also be taken into consideration. The conference hosted representatives of countries, international organizations, business and civic society. A number of initiatives was started in many areas including: technologies, entrepreneurship, taxation and climate change. The undertaking to increase the Official Development Assistance to the level of $0.7 \%$ GNI, including $0.20 \%$ for the least developed countries, was repeated (A/RES/69/313).

Significant changes have also appeared within the European Union. The entry into force of the Lisbon Treaty in 2009 significantly influences the functioning of European development cooperation. New legal frames and institutions were created to increase the importance of the EU on the international stage and to ensure the cohesion of its policy. Pursuant to the Lisbon Treaty, the EU policy in the area of development cooperation is conducted in accordance with the principles and goals of the EU, which includes support of peace and security, sustainable development, fighting poverty and protection of human rights. Eliminating poverty was stated to be the most important target of development cooperation. 
Additionally, the necessity to keep the cohesion of the development policy and other policies was underlined, as the goals of development cooperation must be taken into consideration in all actions that might have influence developing countries. The treaty also introduced important internal reforms enhancing foreign policy. Signing the Lisbon Treaty resulted in creating the European External Action Service and the office of High Representative of the Union for Foreign Affairs and Security Policy, who is the vice-president of the European Commission at the same time. On the one hand, the implementation of the institutional reform brings hope of improvement in the functioning of the European development policy, particularly an increase in cohesion and coordination, but on the other hand, it raises concerns of developing countries related to misuse of development assistance and competence disputes (Nowik, 2011: 428-433).

Brexit is also an important factor shaping the development cooperation of the European Union. The perspective of Great Britain leaving the EU raises much uncertainty related to the future of development cooperation. Great Britain, after Germany and France, is the third biggest net contributor to the budget of the European Union, making it one of the most important actors creating EU policy. UK is also responsible for $15 \%$ of the $11^{\text {th }}$ European Development Fund and one of the major trade partners of developing countries. Leaving the EU and especially the cancellation of decisions regulating economic cooperation (general system of preferential tariffs, free trade agreements, trade partnership agreements) might mean a serious disruption of mutual trade. It might create considerable trade barriers for developing countries in their access to one of the most important markets. It might be particularly negative for the least developed countries and those relying on the British market, for example Belize (30\% of export), Mauritius and Fiji (20\% of export each). The costs of Brexit might also have a negative influence on the level of development assistance provided by Great Britain (Mendez-Parra, Papadavid and Te Velde, 2016: 2-5; Price, 2016; 499-507).

Another aspect worth mentioning is the economic crisis that affected the eurozone. It is an important factor limiting the ambition of the European Union within the frames of executing its international role and position. The above-mentioned challenges and ambitious goals require significant financial spending. At the same time, as a result of the economic crisis, the majority of member states tend to cut their expenditure, also in the area of development policy. It has repeatedly been a serious problem. For example, while working on 
the $11^{\text {th }}$ European Development Fund, the European Commission presented a number of proposals for increasing assistance, but none of them was accepted by the member states and most them pressed for decreasing EU expenditure. In their letter to President Barosso, the leaders of Great Britain, Germany, France, Holland and Finland underlined that "The challenge for the European Union in the coming years will not be to spend more, but to spend better” (Kilnes, 2012: 2).

\section{Potential directions of change in the development policy of the European}

\section{Union}

The European Union took an active role in development of the Agenda for Sustainable Development and, due to that, it adopted a new development agenda with satisfaction, regarding it as fully compliant with its own values. The EU strives to be a pioneer in its execution. Sustainable development is one of the treaty-based principles of the European Union and its goal within the scope of external actions. However, the execution of the new development agenda might be a serious challenge. It is necessary to identify targets and policies. The agenda must be taken into consideration in all internal and external policies with a comprehensive approach tackling all goals of sustainable development, including the connections among three of its dimensions. In the external dimension, the development policy will play a major role in executing the programme of actions. Due to that, the New European Consensus on Development was adopted. It specifies a comprehensive approach within the scope of the programme of actions (COM(2016) 739; O.J. EU, C 210, 30 June 2017).

The ambitious goals of development cooperation require i.a. sufficient financial resources. A chance to execute them appears together with the currently commencing negotiations on the multiannual financial frame of the EU for the period 2021-2028. The official part of the negotiations will begin in May 2018. The most important matters to be settled are the size of the future funds dedicated to Official Development Assistance and the character of the financial instruments (Kugiel, 2018: 1).

Negotiations over the size of the future budget of the European Union seem to be particularly complicated. Currently, the multiannual financial frame (covering the period 2014-2020) constitute only 1.03\% GNI of the European Union. The means earmarked for 
external actions amount to 66.2 billion euros (Section IV - Global Europe), which constitutes about $6.12 \%$ of all measures in the current financial perspective. They are divided among eight financial instruments - four geographical, three subject-matter and one geographical and subject-matter. Not all of those instruments fulfil the criteria of the Official Development Assistance and there are not only developing countries among their beneficiaries. Moreover, the eleventh European Development Fund, currently excluded from the EU budget, holds 30.5 billion euros for ACP countries for the period between 2014 and 2020 (Kengyel, 2017: 8,12; Zajączkowski, 2013a: 650-651).

Those measures are disproportionately small compared to the ambitions and obligations of the European Union. Obliging the EU and the member states to spend $0.7 \%$ GNI on Official Development Assistance until 2030 would require an additional amount of about 40 billion euros. However, due to Brexit and the economic problems of many member states, it seems unlikely that the expenditure for external actions of the European Union will significantly increase. Because of that, the European Commission, in its communication issued in February 2018, suggested an increase in the current level of financing external instruments over the amount of 100 billion (COM(2018) 98 final: 17).

Apart from the level of development assistance, it is important how it is distributed. Currently, the instruments for financing external actions are seen as complicated and timeconsuming in management. Critics underline that the current external actions, including development cooperation, lack a strategic approach. The purpose of the reform of financial instruments should be their simplification, including a reduction in their numbers, which will allow for an increase in assistance efficiency and effectiveness (Di Ciommo, Sherriff and Bossuyt, 2017: 3-7). The new instruments should focus on executing long-distance goals such as liquidation of poverty, sustainable development or supporting democratic governments and human rights.

That is why it is recommended to establish an instrument whose expenditure would be fully qualified as ODA and a separate instrument for humanitarian aid. The purpose of the new instrument should be to support the execution of sustainable development goals (CONCORD, 2017: 8; Di Ciommo, Sherriff and Bossuyt, 2017: 7; OXFAM, 2018: 5-6, 1112). The simplification of instruments can be reached by including the European Development Fund in the Union's budget and joining it with the Development Cooperation 
Instrument. The discussion on it has continued from the early 1970s. Due to historical and political reasons, EDF works outside the EU budget. The special character of EDF was understandable at the moment of its creation in 1958, but currently there is no basis for it, especially because the differences between EDF-funded assistance and the EU budget are not clear anymore (Gaves, 2012: 1; Mackie, Klavert and Aggad, 2010: 8).

It is necessary to increase the effectiveness and flexibility of the measures used. Some experience in this matter is provided by the currently used fiduciary funds and financial instruments combining public and private means. However, the development assistance itself is insufficient and, therefore, it is crucial to prompt the activity of private and business donors. Good examples of such an approach are the EU External Investment Plan and the European Fund for Sustainable Development (Bossuyt and Sherriff, 2017: 3; Latek, 2017: 1$3)$.

The problem with gathering sufficient financial resources and the diversity among developing countries causes the necessity to modify the rules of cooperation. The engagement of the European Union in development will be effective only if it is diversified and takes into consideration the possibilities, needs and problems of different groups of developing countries. That approach resulted in the adoption of the Agenda for Change. It involves treating the poorest countries, the economically vulnerable ones and those with limited perspectives of long-term development as priorities. The financial assistance should be spent on the basis of needs analyses, the capacity of the developing countries to generate their own financial resources, the efficiency in executing the assistance and its potential results. That all means the cancellation of assistance provided in the form of subventions. The Commission proposes providing diversified forms of assistance: technical assistance, preferential loans and commercial cooperation (COM(2011) 637 final: 5-12).

The New European Consensus on Development underlined the necessity to engender innovative cooperation with more advanced developing countries, including other than financial cooperation, as they often do not need any preferential form of support. Those countries are of significant importance for the European Union. On the one hand, they stabilize their regions and are valuable trade partners. On the other hand, due to a vast influence on global public goods and challenges, they are of crucial importance for the execution of Agenda 2030 (O.J. EU, C 210, 30 June 2017: 19-20). 
Issue no. $26 / 2018$

The European Commission consequently decreases its support for the donees classified among the countries of middle and higher income. Part of the observers even claim that in the longer perspective it is possible that the financial assistance is completely cancelled for some developing countries (Herrero, et. al., 2015: 19). At the same time, the European Union adopted a number of regional (for example concerning the Caribbean and the Pacific regions) and subregional (for example: Horn of Africa, Sahel) strategies setting the rules of cooperation, including development cooperation (Carbone, 2013: 750). The negative consequences of that action must also be taken into consideration. Critics of the new development policy of the EU indicate their inadequateness. In accordance with the criteria developed by the World Bank, 81\% of poor people live in countries with a medium income. In spite of relatively good economic rates, many of those countries are vulnerable to disruptions. The least developed countries in turn usually have no efficiency and capacity to effectively use the measures, which can limit the effectiveness of assistance. Consequently, in spite of the declared pursue to liquidate poverty, that goal may be reached only in part (Herbert, 2012: 8-10; Markova, 2013: 11).

Cooperation between the European Union and the countries of Africa, the Caribbean and the Pacific will be subject to change. Official negotiations concerning the future of cooperation will begin in August 2018. The communication of 2016 presents possible options for cooperation and preferences towards them. The first likely scenario assumes resigning from signing a new agreement and further cooperation with ACP states in the present form. In such a case, the relations with ACP as a whole would be substituted with more effective cooperation with particular regional groups or concentrate on selected matters or the countries in biggest need. The second scenario involves prolonging the Cotonou Agreement after its review and update. That option of cooperation will not ensure the necessary cohesion and will not take advantage of the growing regionalism in the ACP states. The last cooperation scenario assumes signing a framework agreement with a whole group of ACP states and detail agreements with single regions. The framework agreement would set general assumptions and goals of cooperation, while the regional agreements would include specific provisions related to political, economic and development cooperation, adjusting to the needs and characteristics of each region (JOIN(2016) 52 final: 29-30; Kugiel and Wnukowski, 2015: 38-40). 
Issue no. 26/2018

\section{Summary: challenges and opportunities for V4 countries}

Changes within international development cooperation, especially those related to the policy of the European Union, create a number of challenges for the states of the Visegrád Group. One of the possible answers to them is the preservation of the present development policy in an unchanged form. In spite of the declared will to execute the goals of sustainable development, the V4 states are not obliged to actually do so. Lack of execution does not cause any negative legal consequences, as the international obligations related to development cooperation are soft law only. These would not be the first not executed declarations of the V4 states on development assistance (for example: the obligation on the level of assistance). On the one hand, it would allow for further use of development assistance for own political and economic reasons related to Eastern Europe and the Balkans and some financial savings due to the lack of need to increase the assistance level. Such an option would surely mean the marginalization of the V4 in the matter, being one of the key elements of international relations. It would particularly have a negative impact on the image of the V4 and its position in the European Union, for which development assistance is one of the most important elements of foreign policy. It would also deteriorate contacts between the V4 and developing countries. Lack of solidarity with developing countries and neutrality towards the efforts of the European Union would also make it difficult to convince Western European states to more intensively engage in V4 projects, for example within the Eastern Partnership. Therefore, the more probable decision is the one of wider engagement in the execution of the new development agenda (Kugiel, 2015: 2). Such a scenario forces the introduction of a number of changes, for which the V4 countries do not seem to be ready.

Undoubtedly one of the biggest challenges faced by the V4 is the lack of political will, which limits both activities and financial resources. Political elites perceive development cooperation more as an unwanted obligation deriving from membership of the EU, OECD or other international organizations, than as an independent instrument of the state's foreign policy. This results in international cooperation being of secondary importance to the foreign policy of the V4. Lack of political will limits social awareness, causes little engagement of the civic society and lack of knowledge on threats deriving from global problems i.a. poverty or climate change. The public opinion of the V4 still sees their countries as poor and struggling against a number of economic and social problems. 
Consequently, politicians do not risk any decision on leading a more intensive development policy as they are afraid of the negative reaction of society. Lack of political will entails lack of knowledge and administrative capacity. The V4 personnel working on the execution of the development cooperation policy is incomparably smaller than the one in Western European countries. Its shortage is deepened by the high level of staff rotation. Consequently, there is lack of experience, knowledge and institutional memory (Lightfoot, 2008: 130-131; SzentIványi and Tétényi, 2013: 829).

The V4 countries should consider the development of new subject areas and selecting new priority countries. A question should be raised whether the V4 has correctly identified and understood their comparative advantage. What is the transformation experience and how can it be shared with other countries? The specialization selection of the V4 countries is controversial. First of all, the selection of supported areas seems unconsidered. The high selfassessment of the V4 in the area of transformation and democracy-building is not confirmed by international analyses. Consequently, there is no consistent concept of implementation of operational goals assessments. Second of all, the selected areas bring minor contributions to development, fighting poverty and improving the situation of societies in developing countries. There is only an indirect relation between those sectors and economic and social development (Jankowski, 2015: 75; Kugiel, 2012: 116). It must also be considered that developing countries might not be interested in economic and political transformation. Third of all, there is no evidence that sharing transformation experience is effective. Ondrej Horky uses the word "myth" to describe it. The concept of system transformation is more an element of rhetoric covering real national interests (Horký, 2012: 27). Due to the above, it seems reasonable to develop new sectors corresponding to the goals of sustainable development and other international obligations. Developing countries, especially those of Sub-Saharan Africa, are more interested in the V4 experience in education, agriculture and development of rural areas. The V4 should also consider modifying the list of their priority countries. Currently, the list is too long in comparison with the limited financial resources, which results in fragmentation and the invisibility of the V4 as donors. It is recommended to select a group of 3-4 African countries on which the effort and resources would be focused. The basis for their selection should be constituted by: the level of their democracy, respecting human rights, level of poverty, rate of human development and historical and contemporary ties. V4 states 
do not have a vision of their relations with African countries and their action are of limited and random by character. Although the majority of V4 countries claim that African countries are their priority, they are in fact practically marginalized (Zajączkowski, 2013b: 4-5). An increase in diplomatic activity of the V4 in Africa is an opportunity to reverse that tendency. It might be gained with bilateral meetings and the adoption of activation programmes for trade, for example Polish “GoAfrica” and Hungarian “Opening to the South” (Cibian, 2017: 12).

The V4 countries should make an effort to increase their financial means earmarked for development assistance. It will be the result of increasing their contribution to the EU, as a consequence of Brexit. Additionally, the possible budgeting of the EDF might result in the V4 countries losing their foregoing preferential contribution pattern for calculating the level of contribution of each country. Some funds can be moved from agricultural policy or cohesion policy to external actions, which would be unprofitable for the V4 countries, which are the biggest receivers of the EU funds (Kugiel, 2018: 2; Kugiel and Wnukowski, 2015: 51). The above would result in an increase in multilateral development assistance on which the V4 have no influence. Therefore, it is suggested to increase the measures dedicated to bilateral aid.

The V4 countries should increase their activity within the institutions of the European Union which decide on development cooperation. Over $70 \%$ of V4 ODA is distributed through the EU structures. In spite of such importance of the European Union, the V4 countries are almost totally insignificant in assemblies working on development assistance. Only by active participation in works on the reform of the policy and its execution after 2020 will the V4 be able to really create the policy of the European Union.

The creation of a common assistance programme of the V4 is a chance to overcome some of the above-mentioned problems. Wider cooperation would result in V4 actions being more effective and the V4 position stronger (Zajączkowski, 2013b: 4). V4 countries can be inspired by the Scandinavian Nordic+ programme and the Visegrad 4-Eastern Partnership Programme (V4EaP) launched by the International Visegrad Fund. Execution of common actions can be held by lack of mutual trust, particularly the reluctance of some V4 countries towards the Polish ambition to be the leader of the group (Kugiel, 2012: 114-115, 118). 
Issue no. $26 / 2018$

\section{Bibliography}

- $\quad$ Addis Ababa Action Agenda of the Third International Conference on Financing for Development (Addis Ababa Action Agenda). Resolution adopted by the General Assembly on 27 July 2015. A/RES/69/313.

- $\quad$ BOSSUYT, J. and SHERRIFF, A. (2017), Strategically financing an effective role for the EU in the world: first reflections on the next EU budget. ECDPM Making policies work, ECDPM [Online] Available from: http://ecdpm.org/wp-content/uploads/MFF-PaperSeptember-2017.pdf [Accessed 15/04/18].

- CARBOnE, M. (2007) The European Union and International Development. London: Routledge.

- CARBONE, M. (2013) Rethinking ACP-EU Relations After Cotonou: Tensions, Contradictions, Prospects. Journal of International Development, Vol. 25 Issue 5, pp. 742756.

- $\quad$ CIBIAN, S. (2017) Central and Eastern Europe and Sub-Saharan Africa Prospects for Sustained Re-engagement. Research Paper, Chatham House, the Royal Institute of International Affairs, [Online] Available from: https:/www.chathamhouse.org/sites/files/chathamhouse/publications/research/2017-05-24cee-sub-saharan-africa-cibian.pdf [Accessed 15/04/18].

- $\quad$ Communication from the Commission to the European Parliament, the European Council and the Council: A new, modern Multiannual Financial Framework for a European Union that delivers efficiently on its priorities post-2020. Brussels, 14.2.2018 COM(2018) 98 final.

- $\quad$ Communication from the Commission to the European Parliament, the Council, the European Economic and Social Committee and the Committee of the Regions: Increasing the impact of EU Development Policy: an Agenda for Change. Brussels, 13.10.2011 COM(2011) 637 final.

- $\quad$ Communication from the Commission to the European Parliament, the Council, the European Economic and Social Committee and the Committee of the Regions: Next steps for a sustainable European future. European action for sustainability. Strasbourg, 22.11.2016 $\operatorname{COM}(2016) 739$ final. 
- $\quad$ CONCORD (2017) Making the case for strong EU development cooperation budget in the next Multiannual Financial Framework. CONCORD Europe Position [Online]. Available from: https://concordeurope.org/wp-content/uploads/2017/12/CONCORDPosition-on-MFF-post2020.pdf?56c6d0\&56c6d0 [Accessed 15/04/18].

- $\quad$ DI CIOMMO, M., SHERRIFF, A. and BOSSUYT J. (2017) The dynamics of EU budget negotiations for external action. Towards a 'single' instrument? Briefing Note. [Online], No. 99. Available from: http://ecdpm.org/wp-content/uploads/ECDPM-2017Briefing-Note-Dynamics-EU-Budget-Negotiations-External-Action.pdf [Accessed 15/04/18].

- $\quad$ GAVES, M. (2012) Replenishing the 11th European Development Fund. Background Note [Online]. Available from: https://www.odi.org/sites/odi.org.uk/files/odiassets/publications-opinion-files/7904.pdf [Accessed 15/04/18].

- GRIMM, S. and HARMER, A. (2005) Diversity in donorship: the changing landscape of official humanitarian aid. Aid donorship in Central Europe, Humanitarian Policy Group, Overseas Development Institute, [Online] Available from: https://www.odi.org/sites/odi.org.uk/files/odi-assets/publications-opinion-files/275.pdf [Accessed 15/04/18]

- $\quad$ HERBERT, S. (2012) Reassessing aid to middle-income countries: the implications of the European Commission's policy of differentiation for developing countries. Working Paper [Online], No. 349. Available from: https://www.odi.org/sites/odi.org.uk/files/odiassets/publications-opinion-files/7710.pdf [Accessed 15/04/18].

- $\quad$ HERRERO, A. et. al. (2015) Implementing the Agenda for Change, An independent analysis of the 11th EDF programming: key findings, Briefing Note. 2015 [Online]. No. 77. Available from: http://ecdpm.org/wp-content/uploads/BN-77-Implementing-Agenda-ChangeSeptember-2015-ECDPM.pdf [Accessed 15/04/18].

- $\quad$ High Representative of the Union for Foreign Affairs and Security Policy (2016) Shared Vision, Common Action: A Stronger Europe A Global Strategy for the European Union's Foreign And Security Policy [Online]. Available from: https://europa.eu/globalstrategy/sites/globalstrategy/files/eugs_review_web.pdf [Accessed 15/04/18]. 
- HORKÝ, O. (2012) The Transfer of the Central and Eastern European 'Transition Experience' to the South: Myth or Reality? Perspectives on European Politics and Society, Vol. 13, No. 1 (April), pp. 17-32.

- HORKÝ, O. and LIGHTFOOT, S. (2012) From Aid Recipients to Aid Donors? Development Policies of Central and Eastern European States. Perspectives on European Politics and Society, Vol. 13, No. 1 (April), pp. 1-16.

- JANKOWSKI, B. (2015) Udział Polski w międzynarodowej współpracy na rzecz rozwoju. Warszawa: Wydawnictwo Uniwersytetu Kardynała Stefana Wyszyńskiego.

- JANUS, H., KLINGEBIEL, S. and PAUlO, S. (2014) "Beyond Aid” and the Future of Development Cooperation. [Online] Briefing Paper. No. 6. https://www.diegdi.de/uploads/media/BP 6.2014_.pdf [Accessed 15/04/18].

- Joint Communication to the European Parliament and the Council: A renewed partnership with the countries of Africa, the Caribbean and the Pacific. Strasbourg, 22.11.2016 JOIN(2016) 52 final.

- Joint Declarations European Parliament, Council European, Commission: Joint statement by the Council and the representatives of the governments of the Member States meeting within the Council, the European Parliament and the Commission. New European Consensus on Development - 'Our world, our dignity, our future'. O.J. EU, C 210, 30 June 2017.

- Joint statement by the Council and the representatives of the governments of the Member States meeting within the Council, the European Parliament and the Commission on European Union Development Policy: 'The European Consensus'. O.J. EU 2006/C 46/01, 24 February 2006.

- $\quad$ KENGYEL, Á. (2017) The next Multiannual Financial Framework (MFF) and its Duration. In-Depth Analysis requested by the BUDG committee [Online]. Available from: http://www.europarl.europa.eu/RegData/etudes/IDAN/2017/603798/IPOL_IDA(2017)60379 8_EN.pdf [Accessed 15/04/18].

- KOPIŃSKI, D. (2011) Visegrad countries’ development aid to Africa: beyond the rhetoric. PCSA Working Papers Series. [Online] No. 4. Available from: http://files.africanstudies.webnode.com/200002556- 
16405173a1/Visegrad_countries_development_aid_to_Africa_beyond_the_rhetoric.pdf [Accessed 15/04/18].

- $\quad$ KUGIEL, P. (2012) The Development Cooperation Policies of Visegrad Countries An Unrealised Potential. The Polish Quarterly of International Affairs, no. 4, pp.101-121.

- KUGIEL, P. (2015) Sustainable Development Goals and Post-2015 Development Agenda. Bulletin. [Online], No. 83 (815). Available from: https://www.pism.pl/files/?id_plik=20407 [Accessed 15/04/18].

- $\quad$ KUGIEL, P. (2018) EU Development Cooperation Policy in the post-2020 Budget. [Online], No. 33 (1104). Available from: https://www.pism.pl/files/?id_plik=24105 [Accessed 15/04/18].

- $\quad$ KUGIEL, P. and WNUKOWSKI D. (2015) Przyszłość partnerstwa UE-AKP po 2020 r. - perspektywa Polski, Polski Instytut Spraw Międzynarodowych, [Online], Available from: http://www.pism.pl/files/?id_plik=21203 [Accessed 15/04/18].

- KILNES, U. (2012) Billions less for development? Analysing drivers and consequences of possible 'zero growth' scenarios for the 11th European Development Fund 2014-2020. Briefing Note. No. 35 [Online], Available from: http://ecdpm.org/wpcontent/uploads/2013/10/BN-35-Less-Development-Analysing-Consequences-European-

Development-Fund-2012.pdf [Accessed 15/04/18].

- $\quad$ LANCASTER, C. (2007) Foreign Aid: Diplomacy, Development, Domestic Politics. Chicago: The University of Chicago Press.

- $\quad$ LATEK, M. (2017) European Fund for Sustainable Development (EFSD), Briefing, European Parliamentary Research Service [Online]. Available from: http://www.europarl.europa.eu/RegData/etudes/BRIE/2016/595837/EPRS_BRI\%282016\%29 595837_EN.pdf [Accessed 15/04/18].

- $\quad$ LIGHTFOOT, S. (2008) Enlargement and the Challenge of EU Development Policy. Perspectives on European Politics and Society, Vol. 9, No. 2, pp. 128-142.

- $\quad$ LUNDSGAARDE, E. (2012) The future of European development aid. Futures, Vol. 44, No. 7 (Special Issue: Welfare Futures, September) pp. 704-710.

- $\quad$ MACKIE, J., KLACERT, H. and AGGAD F. (2010) Bridging the credibility gap Challenges for ACP-EU relations in 2011. Policy and Management Insights. [Online], No. 
77. Available http://ecdpm.org/wp-content/uploads/2013/10/Bridging-Credibility-GapChallenges-ACP-EU-Relations-2011.pdf [Accessed 15/04/18].

- MAH, L. (2014) Reshaping European Union development policy: collective choices and the new global order. Working Papers CEsA, [Online] No. 130. Available from: https://pascal.iseg.utl.pt/ cesa/files/Doc_trabalho/WP130.pdf [Accessed 15/04/18].

- MARKOVA, M. (2013) Scientific or political? Options for the 11th European Development Fund allocation method. Background Note [Online]. Available from: https://www.odi.org/sites/odi.org.uk/files/odi-assets/publications-opinion-files/8450.pdf [Accessed 15/04/18].

- $\quad$ MENDEZ-PARRA, M., PAPADAVID, P. And TE VELDE, D.W. (2016) Brexit and development How will developing countries be affected? Overseas Development Institute, [Online] Available from: https://www.odi.org/sites/odi.org.uk/files/resourcedocuments/10685.pdf [Accessed 15/04/18]

- $\quad$ MERKET, H. (2013) The EU and the Security-Development Nexus: Bridging the Legal Divide. European Foreign Affairs Review. Vol. 18(Special Issue), pp. 83-102.

- Ministry of Foreign and European Affairs of the Slovak Republic (2013) The Medium - Term Strategy for Development Cooperation of the Slovak Republic for 20142018. Bratislava.

- Ministry of Foreign Affairs and Trade of Hungary (2014) International Development Cooperation Strategy and Strategic Concept for International Humanitarian Aid of Hungary. Budapest.

- Ministry of Foreign Affairs of the Czech Republik (2017) Development Cooperation Strategy of the Czech Republic 2018-2030. Prague.

- Ministry of Foreign Affairs Republic of Poland (2015) Multiannual Development Cooperation Programme 2016-2020. Warsaw.

- $\quad$ NOWIK, M. (2011) Wpływ Traktatu Lizbońskiego na kształt współpracy rozwojowej pomiędzy Unią Europejską a krajami AKP. Ekonomia Economics, No. 4 (16), pp. 423-435.

- $\quad$ ODÉN, B. and WOHLGEMUTH, L. (2015) European aid and development policies in a changing world. Some personal reflections. ECDPM Briefing Note, [Online] No. 76. 
Available from: http://ecdpm.org/wp-content/uploads/BN76-European-Aid-DevelopmentPolicies-Changing-World-ECDPM-June-2015.pdf [Accessed 15/04/18].

- OECD, Aid (ODA) disbursements to countries and regions. OECD statistics, http://stats.oecd.org/Index.aspx?DataSetCode=TABLE2A\# [Accessed 15/04/18].

- OECD, Total flows by donor. OECD statistics, http://stats.oecd.org/viewhtml.aspx?datasetcode=TABLE1\&lang=en\# [Accessed 15/04/18].

- $\quad$ OECD (2010), Special Review of Poland, Paris.

- OLSEN, G. (2005) The EU's development policy: Shifting priorities in a rapidly changing world. In: HOEBINK, P. and STOKKE, O. (eds.) Perspectives on European Development Co-operation. London: Routledge, pp. 573-608.

- OXFAM (2018) Development and humanitarian funding in the post-2020 EU Multiannual Financial Framework. Oxfam position on the EU post-2020 MFF [Online]. Available from: http://www.concorditalia.org/wp-content/uploads/2018/02/Oxfam-Positionon-the-MFF-FINAL-February-2018.pdf [Accessed 15/04/18].

- $\quad$ PAPE, E. (2013) An Old Partnership in a New Setting: ACP-EU Relations From a European Perspective. Journal of International Development, Vol. 25 Issue 5, pp. 727-741.

- $\quad$ PAVLIK, P. (2016) From Recipient to Donor Country - Experience from Central Europe. Development, Environment and Foresight, Vol. 2, No. 1, pp. 35-47.

- $\quad$ PRICE, S. (2016) Brexit, Development Aid, and the Commonwealth. The Round Table, Vol. 105, No. 5, pp. 499-507.

- $\quad$ SZENT-IVÁNYI, B. (no date) The Visegrád Countries as Emerging Donors. Aid Allocation and Performance. DemNet Research Papers, [Online] Available from: http://www.demnet.hu/images/stories/B_kiadvanyok/visegrad_tanulmany/visegradi_tanulma ny_eng.pdf [Accessed 15/04/18].

- $\quad$ SZENT-IVÁNYI, B. and TÉTÉNYI, A. (2013) The East-Central European New Donors: Mapping Capacity Building and Remaining Challenges. Journal of International Development, Vol. 25 (6), pp. 819-831.

- $\quad$ Transforming our world: the 2030 Agenda for Sustainable Development. Resolution adopted by the General Assembly on 25 September 2015. A/RES/70/1. 
- VAES, S. HUYSE, H. (2012) Development cooperation in 2020. Leuven: KU Leuven.

- VENTURI, B. and HELLY, D. (2016) A New EU Strategic Approach to Global Development, Resilience and Sustainability. Documenti IAI. [Online], Vol. 16 (14). Available from: http://www.iai.it/sites/default/files/iaiwp1614.pdf [Accessed 15/04/18].

- VENTURI, B. and MAGRO, M. (2016) The EU and the Global Development Framework. A Strategic Approach to the 2030 Agenda. Documenti IAI. [Online], Vol. 16 (5). Available from: http://www.iai.it/sites/default/files/iai1605.pdf [Accessed 15/04/18].

- ZAJĄCZKOWSKI, K. (2013) European Union’s Development Assistance Framework, Priorities and Directions. In: MILCZAREK, D., ADAMCZYK, A. and ZAJĄCZKOWSKI K. (eds.) Introduction to European Studies: A New Approach to Uniting Europe. Warsaw: Centre for Europe, University of Warsaw, pp. 627-662.

- ZAJACZKOWSKI, K. (2013) Opportunities for Central-European countries in the African policy of the EU and the possibility of the reinforced participation of their companies in the implementation of EU Development Aid Schemes in Sub-Saharan Africa. Analysis prepared for the Ministry of Foreign Affairs Republic of Poland. 